\title{
O estilo tardio em Giorgio Agamben
}

\author{
Kelvin Falcão Klein ${ }^{1 *}$ \\ ${ }^{1}$ Universidade Federal do Estado do Rio de Janeiro, Rio de Janeiro/RJ - Brasil
}

\section{RESUMO}

O objetivo deste artigo é resgatar a noção de "estilo tardio", apresentada por Theodor Adorno em ensaio de 1937 e utilizada por Edward Said em livro de mesmo nome, publicado postumamente em 2006. Mais especificamente, o artigo investiga a produtividade hermenêutica de reler a produção mais recente do filósofo Giorgio Agamben a partir da noção de estilo tardio. A hipótese é a de que o recurso ao estilo tardio permite observar de forma privilegiada, na produção de Agamben, um peculiar e produtivo modo de abordar a historicidade dos textos e das imagens. Para aprofundar tal perspectiva, o artigo mobiliza dois grupos principais de obras do autor: em um primeiro momento, é feita a análise de um conjunto de ensaios publicados a partir de 2009; em um segundo e conclusivo momento, propóe-se a análise de dois livros recentes, Autoritratto nello studio, de 2017, e Studiolo, de 2019.

Palavras-chave: estilo tardio; Edward Said; Theodor Adorno; Giorgio Agamben; hermenêutica.

\section{The late style in Giorgio Agamben}

\section{ABSTRACT}

The purpose of the article is to analyze the notion of "late style", first presented by Theodor Adorno in a 1937 essay and used by Edward Said in a book of the same name, published posthumously in 2006. More specifically, the article investigates the hermeneutical productivity of using the notion of late style to read the most recent works of philosopher Giorgio Agamben. The hypothesis is that the use of late style allows us to observe in Agamben's works a peculiar and productive way of approaching the historicity of texts and images. To deepen this perspective, the article analyses two main groups of works by the

DOI: http://dx.doi.org/10.1590/2237-101X02204604

Artigo recebido em 10 de fevereiro de 2020 e aceito para publicação em 14 de junho de 2020.

* Professor da Universidade Federal do Estado do Rio de Janeiro / Centro de Letras e Artes / Programa de Pós-Graduação em História, Rio de Janeiro/RJ - Brasil. E-mail: kelvin.klein@gmail.com. ORCID: https:// orcid.org/0000-0002-8997-1174. 
author: a set of essays published since 2009 and two recent books, Autoritratto nello studio, from 2017, and Studiolo, from 2019.

Keywords: late style; Edward Said; Theodor Adorno; Giorgio Agamben; Hermeneutics.

\section{El estilo tardío en Giorgio Agamben}

\section{RESUMEN}

El objetivo de este artículo es rescatar la noción de "estilo tardío", presentada por Theodor Adorno en un ensayo en 1937 y utilizada por Edward Said en el libro del mismo nombre, publicado póstumamente en 2006. Específicamente, el artículo investiga la productividad hermenéutica de releer la producción más reciente del filósofo Giorgio Agamben a partir de la noción del estilo tardío. La hipótesis es que el recurso del estilo tardío permite observar de forma privilegiada, en la producción de Agamben, un peculiar y productivo modo de abordar la historicidad de los textos y de las imágenes. Para profundizar en esta perspectiva, el artículo moviliza dos grupos principales de obras del autor: en un primer momento, es hecho un análisis de un conjunto de ensayos publicados a partir de 2009; en un segundo y conclusivo momento, se propone el análisis de dos libros recientes, Autoritratto nello studio, de 2017, e Studiolo, de 2019.

Palabras clave: estilo tardío; Edward Said; Theodor Adorno; Giorgio Agamben; hermenéutica.

1.

Edward W. Said, crítico cultural de ampla projeção na segunda metade do século XX, usou a expressão "estilo tardio" para dar nome a um de seus livros póstumos, On Late Style: Music and Literature Against the Grain, lançado em 2006, três anos após sua morte. "Edward estava às voltas com a redação deste livro quando faleceu na manhã de uma terça-feira, 25 de setembro de 2003", escreve Miriam Said no prólogo, acrescentando ainda que "a ideia deste livro - a 'obra tardia', o 'estilo tardio' de escritores, músicos e outros artistas - surgiu nas conversas de Edward lá pelo fim da década de 1980", até que, "no começo da década de 1990, ofereceu um curso inteiro sobre o tópico" (SAID, 2009, p. 7-8). Ou seja, trata-se de um tema explorado por Said ao longo de anos e, considerando o caráter inacabado do livro Estilo tardio, ainda em processo de desenvolvimento'.

\footnotetext{
${ }^{1}$ Procuro aqui ampliar e, ao mesmo tempo, especificar em um caso emblemático a produtividade da categoria exposta por Said a partir de Adorno. Nisso sigo a indicação já dada por Alcides Villaça em seu texto sobre 
É o próprio Said quem indica - no primeiro ensaio do livro, intitulado "O oportuno e o tardio" - que a noção de "estilo tardio" foi aproveitada de Theodor W. Adorno, que usou a expressão em um "fragmento de ensaio" intitulado "O estilo tardio de Beethoven", datado de 1937 e "incluído em 1964 num volume de ensaios musicais, Moments musicaux" (SAID, 2009, p. 27). Said argumenta que a noção de estilo tardio funciona para Adorno como uma fuga do biografismo, ou seja, como uma possível estratégia crítica (no caso específico de sua abordagem à obra tardia de Beethoven) para descolar a arte produzida no fim da vida do fato biográfico da morte iminente. É a partir desse esforço de esvaziamento do biografismo excessivo que Said chega à fórmula: "O estilo tardio é o que se dá quando a arte não abdica de seus direitos em benefício da realidade" (SAID, 2009, p. 29).

O estilo tardio vai paulatinamente sendo definido por Said, a partir e para além de Adorno, como algo que se dá na obra de um artista ou pensador no fim de sua vida e que, ao mesmo tempo, recusa o aspecto determinista da morte (ou, ao menos, da iminência da morte). "Para Adorno", continua Said, "a noção tem a ver com uma sobrevivência além do aceitável e do normal", não deixando espaço para "a transcendência ou para a unidade"; "viver essa condição tardia significa viver rumo ao fim, com plena consciência, com plena memória e com total (e mesmo extraordinária) ciência do presente" (SAID, 2009, p. 33-34). O estilo tardio parece, de alguma forma, recusar a imediaticidade do presente e, ao mesmo tempo, se dedicar a uma leitura do contemporâneo que não perca de vista a memória do passado, a recuperação de camadas prévias da experiência. Tal peculiar modo de escrita indicaria uma instabilidade na harmonização da percepção dos tempos e das épocas por parte de quem escreve: "ser tardio é portanto uma espécie de exílio autoimposto diante de tudo o que costuma ser aceito, um exílio posterior e sobrevivente a isso", escreve Said, acrescentando que se trata de uma articulação entre "tensão contínua", "obstinação irrequieta" e "conjunçáo do novo e do tardio" (SAID, 2009, p. 36-37).

É preciso frisar que Said não necessariamente busca analisar o estilo tardio em Adorno. Antes, trata-se de uma espécie de recapitulaçáo do uso que faz Adorno da expressão (especialmente em seus ensaios sobre música), encaminhando tal recapitulação em direçáo a uma constatação de aplicação geral: Adorno identifica o estilo tardio ao desconforto do artista diante do mundo e diante da própria finitude; Said, por sua vez, identifica em toda a obra de Adorno certa tendência a valorizar aquilo que se realiza (em arte e em teoria) "contra a corrente de seu tempo" (SAID, 2009, p. 42). É preciso ter em mente tal movimento

o livro de Said: "Essa 'plataforma' instigante pode dar ainda muitos frutos. Se há, como já houve, restrições possíveis à aplicação do conceito (para quem julga, por exemplo, que Said não considerou mais verticalmente a circunstância histórica de cada obra que interpretou), os desdobramentos propiciados pela compreensão do estilo tardio podem ser estímulos imediatos (sob o eterno risco da mecanização) para novos lances interpretativos. Aqui no meu canto de leitor brasileiro, algumas fantasmagorias sorriram para mim, enquanto ia lendo Said: o Machado de Assis maduro, o Drummond dos anos 1950 e da máquina do mundo, o Graciliano de $S$. Bernardo, a Clarice de $A$ hora da estrela pareciam algo insatisfeitos com as canonizaçóes já obtidas. É esse, aliás, o efeito das grandes provocaçôes críticas: colocar-nos em novas encruzilhadas" (VILLAÇA, 2010, p. 380). 
para que seja possível esclarecer o parágrafo de encerramento do ensaio de Said, no qual ele escreve: "O estilo tardio faz parte e, ao mesmo tempo, está à parte do presente", ou seja (Adorno elabora a partir de Beethoven), "o estilo tardio não admite as cadências definitivas da morte; nele, ao contrário, a morte aparece como refração, como ironia. E, contudo”, finaliza Said, "a ironia maior está em que, na solenidade opulenta, fraturada e de algum modo inconsistente de obras como a Missa solemnis ou os ensaios de Adorno, a condição tardia como tema e como estilo - acabe sempre por nos falar de morte” (SAID, 2009, p. 44).

2.

Gostaria de rastrear essa dupla condição do estilo tardio - tensão diante da corrente do tempo e insistência no tema da morte - na obra do filósofo italiano Giorgio Agamben, com o intuito de reconfigurar certos traços da sua produção a partir desse detalhe hermenêutico aproveitado de Said e Adorno ${ }^{2}$. A hipótese é a de que o recurso ao estilo tardio permite observar de forma privilegiada, na produção de Agamben, um peculiar e produtivo modo de abordar a historicidade dos textos e das imagens. Em linhas gerais, trata-se daquilo que Agamben comenta em seu ensaio "O que é o contemporâneo?" (originalmente a aula inaugural de seu curso de 2006-2007 na Università Iuav di Venezia), no sentido duplo e simultâneo de ser contemporâneo e de estar contemporâneo: "o contemporâneo não é apenas aquele que, percebendo o escuro do presente, nele apreende a resoluta luz", escreve Agamben, "é também aquele que, dividindo e interpolando o tempo, está à altura de transformá-lo e de colocá-lo em relação com os outros tempos", ou seja, "de nele ler de modo inédito a história,

\footnotetext{
${ }^{2}$ A discussão sobre o estilo tardio (a partir de Said e Adorno) tangencia a problemática mais ampla daquilo que Frank Kermode chamou, no livro de mesmo nome, de "The Sense of an Ending" (a "percepção do fim" ou, na traduçáo portuguesa do livro, A sensibilidade apocalíptica - publicado pela primeira vez em 1967 pela Oxford University Press, teve origem nas Palestras Mary Flexner, dadas no Bryn Mawr College em 1965). Kermode apresenta uma enorme variedade de exemplos para argumentar que a "sensibilidade apocalíptica" é culturalmente recorrente e sempre historicamente renovada: "na nossa crise perpétua, temos, nas épocas próprias, talvez sob a pressão do nosso próprio fim, perspectivas entontecedoras sobre o passado e o futuro, numa liberdade que é a liberdade da realidade discordante" (KERMODE, 1997, p. 172-173). Poucos anos antes das palestras de Kermode, em 1959, Norman O. Brown publica Vida contra morte: o sentido psicanalítico da história, em cujo oitavo capítulo, intitulado "Morte, Tempo e Eternidade", o autor escreve: "Qual é a relação entre fixação ao passado e a repressão da morte? Torna-se evidente o termo intermediário: a recusa a envelhecer. [...] Se a morte proporciona individualidade na vida e se o homem é o organismo que reprime a morte, então o homem é o organismo que reprime sua própria individualidade" (BROWN, 1972, p. 128130). Em seu célebre ensaio de 1966, "O fardo da História", Hayden White celebra o livro de Brown como "o equivalente historiográfico do anti-romance", afirmando que o autor tenta "lançar mão das modernas técnicas artísticas de um modo significativo" (WHITE, 2014, p. 57). Brown seguiu investigando a relação entre narrativa histórica, pulsão de morte e sensibilidade apocalíptica em sua obra posterior, com destaque para Closing Time, de 1973 (resenhado justamente por Edward Said, no The New York Times Book Review de 9 de setembro de 1973), e Apocalypse and/or Metamorphosis, de 1991.
} 
de 'citá-la' segundo uma necessidade que não provém de maneira alguma do seu arbítrio, mas de uma exigência à qual ele não pode responder" (AGAMBEN, 2009, p. 72).

A ideia agambeniana de estar e de agir no contemporâneo, portanto, se aproxima da natureza do estilo tardio que Said resgata de Adorno - ou seja, a mescla de "tensão contínua", "obstinação irrequieta" e "conjunção do novo e do tardio". Em ensaio de 2011, publicado em volume coletivo de homenagem a Giorgio Baratta (reconhecido filósofo especialista na obra de Antonio Gramsci), Pietro Clemente não só aproxima os projetos de Agamben e Said em torno do estilo tardio como posiciona o esforço conceitual do primeiro em um panorama de referências que abarcaria, entre outros, Ernesto de Martino, Benedetto Croce e o próprio Gramsci (CLEMENTE, 2011, p. 455). A partir da perspectiva de Clemente, é possível dizer que o estilo tardio é um desdobramento em filigrana de uma questão teórica que percorre o século XX (embora tenha já sido apontada por Nietzsche em fins do século XIX): a crítica de um paradigma teleológico de relacionamento com o tempo e a história.

O próprio Agamben tem consciência disso, especialmente quando estabelece Walter Benjamin e Michel Foucault como sustentáculos principais da sua abordagem, o primeiro por conta de sua ideia de que "o índice histórico contido nas imagens do passado mostra que estas alcançarão sua legibilidade somente num determinado momento da sua história”, e o segundo "quando escrevia que as suas perquirições históricas sobre o passado são apenas a sobra trazida pela sua interrogação teórica do presente", ambos convergindo na necessidade metodológica de "ser contemporâneo não apenas do nosso século e do 'agora', mas também das suas figuras nos textos e nos documentos do passado" (AGAMBEN, 2009, p. 72-73).

Quando publica a conferência sobre o contemporâneo em livro - Nudità, de 2009 -, Agamben acrescenta também no volume um ensaio sugestivamente intitulado "O último capítulo da história do mundo" ("L'ultimo capitolo della storia del mondo"). O artigo é também o último capítulo do livro, oferecendo de forma bastante condensada uma espécie de arremate das principais ideias de Agamben em Nudità. Além disso, dá continuidade às reflexôes iniciadas no ensaio sobre o contemporâneo, na medida em que se ocupa de uma reorganizaçáo do pensamento diante de um momento de fim ou encerramento. Agamben inicia o ensaio afirmando que as estratégias da ignorância são tão relevantes quanto as do conhecimento; ou seja, é preciso aperfeiçoar a "arte da ignorância" do mesmo modo como se aperfeiçoou, por séculos, a "arte do conhecimento" e da "transmissão do saber" (AGAMBEN, 2010, p. 161-162). Não fica claro a qual disciplina se volta o autor - um traço recorrente na feitura não só de Nudità, mas de boa parte da obra de Agamben -, embora se reconheça um campo heterogêneo delineado nas fronteiras da história, da literatura, da teologia e especialmente da filosofia. É preciso saber absorver a ignorância e aquilo que escapa das estratégias da epistemologia, afirma Agamben, especificando que não se trata de mística (que exalta a obscuridade), de liturgia (que glorifica o arcano) ou de psicanálise (que enche o náo-saber de fantasmas) (AGAMBEN, 2010, p. 163). Diante do não-saber, o saber trabalharia em um 
registro de confronto hierárquico, vendo-o como uma terra a ser conquistada - trata-se, contudo, segundo Agamben, de estabelecer uma relaçáo de mútuo estímulo.

Diante disso, é possível argumentar que o estilo tardio, além de apostar na tensão entre passado e presente (ou entre continuidade e descontinuidade), explora também a incontornável relação entre saber e não-saber, relação que parece alcançar um grau mais elevado de legibilidade na iminência de um momento de fim ou encerramento (seja do mundo, de uma publicação ou mesmo da vida). Nos últimos trabalhos de Agamben, a tensão entre saber e não-saber foi muitas vezes aproximada da tensão entre potência e ato, ou seja, entre a possibilidade de fazer algo e a possibilidade de escolher não fazê-lo. Em Opus Dei, livro de 2012, glosando a interpretação latina dos Pais da Igreja da filosofia aristotélica (dentro do escopo mais amplo daquilo que denomina "arqueologia do ofício", ou seja, uma investigação da matriz conceitual da ontologia moderna a partir das traduçóes de termos-chave do grego para o latim), Agamben escreve: "Como Aristóteles não se cansa de repetir contra os megáricos, tem verdadeiramente uma potência aquele que pode tanto colocá-la quanto não colocá-la em ato"; completando mais adiante com um exemplo: "O Bartleby de Melville, ou seja, por definição um homem que tem a potência de escrever, mas não pode exercê-la, é a perfeita das aporias da ética aristotélica" (AGAMBEN, 2013, p. 100, 103).

Assim como o saber precisa dar conta do não-saber - a partir de uma "arte da ignorância" que exercite a noção de que as certezas são historicamente situadas e, por isso, oscilantes - a potência precisa dar conta da própria suspensão ou esvaziamento, do reconhecimento de certa não-continuidade em sua vigência. Ainda em $O p u s$ Dei, Agamben escreve que a "relação com a privação", ou seja, com a possibilidade de não-fazer (ou não-saber), "é essencial para Aristóteles, porque é só através dela que a potência pode existir como tal, independentemente de seu passar ao ato" (AGAMBEN, 2013, p. 99). Agamben aprofunda a questão em um dos ensaios de seu livro Il fuoco e il racconto ( $O$ fogo e o relato), publicado dois anos depois de Opus Dei, em 2014. O ensaio se chama "Che cos'è l'atto di creazione?" "“O que é o ato de criação?") e está inteiramente dedicado à tensão entre "potência" e "potência-de-não", colocando em primeiro plano uma preocupaçáo conceitual e metodológica que, em Opus Dei, era ainda periférica. "A potência é um ser ambíguo", escreve Agamben, "que não apenas pode tanto uma coisa quanto seu contrário, mas contém também em si uma íntima e irredutível resistência"3 (AGAMBEN, 2014, p. 46).

É preciso apontar ainda que a pergunta do título do ensaio de Agamben retoma aquela de Gilles Deleuze, que deu o mesmo título a uma conferência de março de 1987. Para Deleuze, o ato de criação é um ato de resistência, especialmente de resistência à morte e ao paradigma da informação dominante na sociedade de controle (AGAMBEN, 2014, p. 39). Diante do que foi posto até aqui, é possível argumentar que o estilo tardio apresenta de forma mais

\footnotetext{
${ }^{3}$ Tradução minha. No original: "La potenza è un essere ambiguo, che non solo può tanto una cosa che il suo contrario, ma contiene in se stessa un'intima e irriducibile resistenza".
} 
pronunciada uma série de características que, a partir de Agamben, dizem respeito ao ato de criação de forma ampla e ao ato de escrita de forma específica: conjunção tensa entre novo e tardio, abertura crítica para o não-saber e para a potência-de-não e, resgatando algo que foi atestado também por Said, uma direta resistência à morte. Em outro ensaio de Il fuoco e il racconto (intitulado "Do livro à tela"), Agamben retoma os mesmos temas por um outro viés e com outro exemplo: o último curso de Roland Barthes no Collège de France, intitulado A preparação do romance. "Logo no início, quase como um presságio da morte iminente", escreve Agamben, "Barthes evoca o momento da vida no qual se começa a entender que ser mortal não é mais um sentimento vago, mas uma evidência"‘ (AGAMBEN, 2014, p. 87). A iminência do fim faz com que Barthes se dedique à escrita de modo novo e o tema de seu curso reflete essa decisão: não se trata tanto do ato de escrever, mas do "querer-escrever", ou seja, do problema do "fantasma do romance", seu caráter intermediário entre ideia e artefato pronto, aquilo que vem antes do livro e que, ainda assim, é indispensável àquilo que o livro, por fim, se torna (AGAMBEN, 2014, p. 88).

De volta ao ensaio sobre o ato da criação, tendo em mente essa aproximação (já canônica, em certo sentido) entre estilo tardio e reflexáo sobre a morte, é preciso ressaltar que ainda no começo de sua argumentação Agamben recorre a um autor importante no contexto que tentamos aqui delinear: Ludwig Feuerbach. A passagem no ensaio sobre o ato da criação no qual Agamben cita Feuerbach parece só alcançar toda sua carga de sentido quando aproximada daquela citada acima, sobre o estilo tardio de Barthes em $A$ preparação do romance. Isso porque Agamben inicia seu comentário a partir de uma reflexão sobre seu próprio trabalho: "depois de tantos anos lendo, escrevendo e estudando", escreve ele, "acontece, às vezes, de entender qual seja nosso modo especial de proceder no pensamento e na pesquisa"; em seu caso, continua Agamben, "se trata de perceber aquilo que Feuerbach chamava 'capacidade de desenvolvimento' contida na obra dos autores que amo"s (AGAMBEN, 2014, p. 40). Agamben defende que o que há de "genuinamente filosófico" em qualquer obra é sua dimensão não dita e não pensada, algo que lança em direção ao futuro (para além de seu fim iminente, em suma) uma possibilidade de desenvolvimento que deve ser apreendida.

Nesse ponto específico, é possível recordar que Said trabalha a noção de estilo tardio a partir de Adorno confiando precisamente em sua "capacidade de desenvolvimento", ou seja, construindo seu próprio campo argumentativo a partir daquilo que permaneceu lacunar em Adorno. Ainda mais especificamente, Said aprofunda suas reflexôes sobre o estilo tardio bus-

\footnotetext{
${ }^{4}$ Tradução minha. No original: "Proprio all'inizio, quasi per un presagio della morte imminente, Barthes evoca il momento della vita in cui si comincia a capire che essere mortali non è piú un sentimento vago, ma un'evidenza”.

5 Tradução minha. No original: "Dopo tanti anni passati a leggere, scrivere e studiare, capita, a volte, di capire quale sia il nostro modo speciale - se ve n'è uno - di procedere nel pensiero e nella ricerca. Si tratta, nel mio caso, di percepire quella che Feuerbach chiamava la 'capacità di sviluppo' contenuta nell'opera degli autori che amo".
} 
cando o "teor estranhamente recapitulativo e mesmo passadista, alheado" de certas obras tardias, como as de Genet, Luchino Visconti e Richard Strauss (SAID, 2009, p. 45). Comentando este último, Said salienta a "adoção persistente" e o "retorno a versões novecentistas de linguagens e formas setecentistas que distingue o estilo de Strauss", "no exato momento em que o movimento moderno produzia aqueles outros estilos mais evidentemente avançados ou realistas como o dodecafonismo e o serialismo" (SAID, 2009, p. 50-51). Ou seja, a "capacidade de desenvolvimento" teorizada por Feuerbach e resgatada por Agamben em seu próprio trabalho já faz parte (de forma não expressa) do movimento de expansão da noção de estilo tardio por parte de Said, a partir de Adorno. Mais do que isso: o exercício do estilo tardio nos estudos de caso de Said mostra que tal estilo se caracteriza por um peculiar movimento "recapitulativo", ou ainda, pelo esforço deliberado de investigar aquilo que ainda pode ser desenvolvido em obras do passado. O estilo tardio pressupóe, portanto, um gesto de reorganização e reconfiguração dos elementos resgatados do passado que são passíveis de desenvolvimento.

A noção de Feuerbach faz sua primeira aparição na obra de Agamben em uma conferência de 2005 intitulada "O que é um dispositivo?". O ponto da conferência no qual surge Feuerbach é bastante próximo ao texto do ensaio sobre o ato da criação (publicado em $O$ fogo e o relato, em 2014, mas também este resultado de uma conferência, proferida em novembro de 2012 em Mendrisio), uma vez que Agamben inicia dizendo que "um dos princípios metodológicos que sigo constantemente em minhas pesquisas é aquele de individuar nos textos e nos contextos em que trabalho o que Feuerbach definia como o elemento filosófico", ou seja, completa ele, "o ponto de sua Entwicklungsfähigkeit, o locus e o momento em que estes são passíveis de aprofundamento" (AGAMBEN, 2005, p. 12-13). Em 2008 Agamben retorna à noção de Feuerbach, dessa vez em Signatura rerum, seu livro sobre método (composto de três capítulos: "O que é um paradigma?", “Teoria das assinaturas" e "Arqueologia filosófica”). Ele aponta, já na advertência inicial, os princípios metodológicos que norteiam o trabalho: um deles é aquilo "que Feuerbach definia como Entwicklungsfähigkeit", ou seja, o princípio que diz que "o elemento genuinamente filosófico em cada obra, seja ela obra de arte, de ciência ou de pensamento, é sua capacidade de ser desenvolvida"; "quando se segue tal princípio", continua ele, "a diferença entre o que é do autor da obra e o que deve ser atribuído a quem a interpreta e a desenvolve se torna tão essencial quanto difícil de se apreender" (AGAMBEN, 2019a, p. 8).

O uso que Agamben faz de Feuerbach, portanto, se organiza, até aqui, em torno a três pontos: a conferência sobre o dispositivo de 2005, a publicação de Signatura rerum em 2008 e, por fim, o ensaio sobre o ato de criação, fruto de uma conferência de 2012, publicado no livro de 2014, O fogo e o relato. Recentemente, em 2017, a revista francesa Critique organizou um número temático dedicado a Agamben. Nele, Agamben participa de um diálogo com Patrick Boucheron intitulado "O arqueólogo e o historiador", além de contribuir com dois artigos inéditos, publicados pela primeira vez diretamente em francês: "Principia Herme- 
neutica" e "Sur l'écriture des préambules". O primeiro dos artigos é uma espécie de compilação dos principais eixos metodológicos de trabalho de Agamben ao longo de sua obra, dividida em seis princípios: princípio de Benjamin-Ticônio, princípio de Feuerbach, princípio de Coleridge, dois princípios de Orígenes, e o princípio de Overbeck-Foucault ${ }^{6}$. Trata-se, até o momento, do texto no qual Agamben melhor especifica aquilo que pretende com o resgate da "capacidade de desenvolvimento": escreve que o princípio de Feuerbach está em sua monografia sobre Leibniz, publicada em 1837 como segundo volume de sua História da filosofia moderna, postulando que a capacidade de desenvolvimento (Entwicklungsfähigkeit) é uma atividade tanto analítica quanto sintética, na medida em que busca desenvolver o não dito (nicht gesagt) daquilo que interpreta e também busca deduzir seu cerne a partir de uma multiplicidade de reflexóes isoladas (AGAMBEN, 2017b, p. 6).

É possível dizer, portanto, que em seus últimos escritos Agamben foi, pouco a pouco, dando mais espaço à ideia de "capacidade de desenvolvimento" de Feuerbach, posicionando-a em paralelo a outras noçóes. Nessa perspectiva, percebe-se que Agamben não só exercita certo estilo tardio peculiar ao seu pensamento, mas, no processo de elaboraçáo de tal estilo, oferece também reflexóes teóricas e conceituais que se aproximam daquilo que Said argumenta diretamente como atinentes ao estilo tardio (com ênfase na conjunção tensa entre temporalidades e a reflexão pronunciada sobre a iminência do fim). Como seção de encerramento deste artigo, proponho a leitura detida de dois outros livros recentes de Giorgio Agamben, com o intuito de aprofundar e exemplificar o que foi exposto até aqui.

3.

Em 2017, Agamben publica o livro Autoritratto nello studio ("autorretrato no estúdio" ou "escritório"), uma espécie de autobiografia intelectual na qual repassa os principais eventos

\footnotetext{
${ }^{6}$ Os princípios são apresentados por Agamben numerados e seguidos de seus comentários. Em linhas gerais, os princípios estão expostos da seguinte forma (não coloco aqui o de Feuerbach, comentado no corpo do texto): Princípio de Benjamin-Ticônio: "A doutrina só pode ser exposta de forma legítima sob a forma da interpretação", ou ainda: "As regras da interpretação são a doutrina"; Princípio de Coleridge: "Until you understand a writer's ignorance, presume yourself ignorant of his understanding"; Primeiro princípio de Orígenes: "As portas da Escritura estão fechadas e as chaves foram misturadas"; Segundo princípio de Orígenes: "O sentido espiritual não é outro sentido literal"; Princípio de Overbeck-Foucault: "Toda investigaçấo histórica deve a certo ponto necessariamente se medir com um estrato pré-histórico que constitui seu a priori histórico. A busca que lida com esse a priori histórico toma a forma de uma arqueologia" (AGAMBEN, 2017b, p. 5-13). A reflexão de Agamben acompanhada até aqui e condensada nesses princípios hermenêuticos pode ser produtivamente aproximada da reflexão de Reinhart Koselleck, em especial no texto "Quão nova é a modernidade?" (uma conferência de 1989 hoje disponível no volume Estratos do tempo), quando escreve que "a história contém numerosos estratos distinguíveis, que mudam de forma ora mais rápida, ora mais lenta, mas certamente em ritmos distintos"; consequentemente, "se quisermos saber quão nova é a nossa modernidade, precisamos saber quantos estratos da história antiga estão contidos no presente” (KOSELLECK, 2014, p. 221).
} 
e as principais leituras de sua trajetória. O relato, contudo, não é feito de modo cronológico ou organizado a partir, digamos, de um registro jornalístico. Pelo contrário, o "autorretrato" de Agamben se apresenta antes de tudo como uma reflexão sobre o local de trabalho, a mesa, o estúdio ou escritório, o espaço no qual se passa "da potência ao ato": "tentar descrever o próprio estúdio significa a tentativa de descrição dos modos e formas da própria potência - uma tarefa, ao menos à primeira vista, impossível"7 (AGAMBEN, 2017a, p. 13). O livro também conta com várias ilustraçóes - reproduçôes de fotografias, cartas, anotaçóes, quadros, retratos de artistas e pensadores -, que sáo incorporadas ao corpo do texto, por vezes interrompendo o fluxo da narrativa, funcionando como apoio documental às informaçôes do texto e também relatos visuais suplementares e independentes. A primeira seçâo do livro é intitulada "limiar" (soglia) e estabelece a emissão de Agamben no interior do estilo tardio: fala de um espaço alcançado na velhice no qual só se pode entrar, e não sair; fala dos "temas de uma vida" que, mesmo parecendo distantes, permanecem sempre "incompletos" de um ciclo de perpétuo comentário (AGAMBEN, 2017a, p. 9-10).

A primeira reminiscência evocada é aquela de Martin Heidegger, especialmente o curso privado oferecido por ele em Le Thor, no interior da França, em 1966, do qual Agamben participou. O grupo que acompanhou as liçóes é mencionado (René Char, Jean Beaufret, Dominique Fourcade, Ginevra Bompiani, entre outros), bem como os outros grupos de intelectuais que Agamben frequentava, especialmente em Roma (dos quais faziam parte, entre outros, Pier Paolo Pasolini, Elsa Morante e Juan Rodolfo Wilcock). Agamben também destaca o começo de sua leitura das obras de Hannah Arendt (em decorrência do contato com Heidegger) e o momento em que manda uma carta a ela, anexando um ensaio escrito a partir do contato com sua obra (um ensaio de 1968 intitulado "Sobre os limites da violência”). Arendt não apenas respondeu como incluiu uma referência ao ensaio de Agamben em uma das notas da edição alemã de Sobre a violência, além de repassar o ensaio para Mary McCarthy.

Depois de Heidegger, é destacada a presença de Nicola Chiaromonte, diretor da revista Tempo Presente, na qual Agamben publica seus primeiros trabalhos, em 1966 e 1967. Agamben destaca o livro que Chiaromonte publica em 1971, Crer e não crer, como determinante para sua formação, acrescentando um comentário sobre "algumas páginas de seus cadernos de anotaçóes" com "uma extraordinária meditação sobre o que resta de uma vida" (Chiaromonte falece no ano seguinte, 1972), que o próprio Agamben incorpora ao seu autorretrato (AGAMBEN, 2017a, p. 29-30). Em seguida, aproveitando elementos encontrados na mesa de trabalho (um livro e uma fotografia), Agamben fala de Herman Melville e

\footnotetext{
${ }^{7}$ Tradução minha. No original: "Provare a descrivere il proprio studio significa allora provare a descrivere i modi e le forme della propria potenza - un compito, almeno a prima vista, impossibile”.

${ }^{8}$ Traduçáo minha. No original: "E anche quando sembrano situati in un passato remoto, i temi della vita sono necessariamente incompiutti, come una melodia o una fuga interrotta che aspetta di essere continuata e ripresa”.
} 
Guy Debord, aproximados por um mesmo traço: ambos se encontram, de certa forma, em dissonância com o próprio tempo, insuficientes e, ao mesmo tempo, excessivos (atuantes na "contemporaneidade do não contemporâneo", para usar mais uma vez as palavras de Koselleck (2013, p. 39)). Agamben argumenta que é só no contraste diante do outro que é possível, para ele, dizer "eu": "quero que uma coisa apareça com clareza: sou um epígono no sentido literal da palavra, um ser que se cria só a partir de outros e não renega jamais essa dependência, vive em uma contínua, feliz epigênese"9 (AGAMBEN, 2017a, p. 42).

Nesse ponto já se delineia com clareza um procedimento recorrente de Agamben em seu autorretrato: ele muitas vezes posiciona as figuras relembradas em duplas, funcionando como polos opostos de atração com relação ao ponto focal desempenhado pelo narrador. Heidegger e Chiaromonte, seguidos por Debord e Melville, chegando em uma sucessão de outros pares: Manganelli e Gadda; Manganelli e Ingeborg Bachmann; Scholem e Adorno (ambos encontrados por Agamben por intermédio de Bachmann); José Bergamín e Simone Weil; José Bergamín e Giovanni Urbani; Giorgio Caproni e Sebastião Salgado; Pierre Klossowski e Jean-Luc Nancy; Robert Walser e Hölderlin, e assim por diante. Como fez com Heidegger no início, um pouco além da metade do livro Agamben se detém em outro autor fundamental para sua carreira, Walter Benjamin. “O que devo a Benjamin?”, se pergunta Agamben, e responde: "a capacidade de extrair e arrancar à força de seu contexto histórico aquilo que me interesse, restituindo vida e fazendo agir sobre o presente. A operação é realizada com todas as possíveis cautelas filológicas, mas até o fim e de forma decisiva”; na continuação do parágrafo, Agamben parece resgatar a Entwicklungsfähigkeit de Feuerbach, embora não o mencione diretamente: "Benjamin é o único autor cuja obra quis, na medida de minhas forças mas sem reservas, continuar"10 (AGAMBEN, 2017a, p. 103).

Esse relacionamento de Agamben com Walter Benjamin se torna ainda mais próximo na década de 1980, durante uma pesquisa que realiza na Biblioteca Nacional da França, em Paris. Investigando os papéis de Georges Bataille, Agamben encontra uma série de pastas com manuscritos inéditos de Walter Benjamin, todas elas dentro de um armário pertencente a Bataille e custodiado pela Biblioteca desde a II Guerra Mundial. Nesse ponto de sua rememoração, Agamben faz do "desenvolvimento" da obra de Benjamin uma tarefa física e material, envolvendo a manipulação direta dos manuscritos e a decifração meticulosa da caligrafia - "clara e legível quando escrevia em francês, mas árdua de decifrar quando escrevia

\footnotetext{
${ }^{9}$ Tradução minha. No original: "Una cosa vorrei, però, che apparisse con chiarezza: che io sono un epigono nel senso letterale della parola, un essere che si genera solo a partire da altri e non rinnega mai questa dipendenza, vive in una continua, felice epigenesi".

${ }^{10}$ Tradução minha. No original: "Che cosa devo a Benjamin? Il debito è cosi incalcolabile, che non posso nemmeno provare a rispondere. Ma certamente una cosa: la capacità di estrarre e strappare a forza dal suo contesto storico ciò che mi interessa per restituirgli vita e farlo agire nel presente. L'operazione va eseguita con tutte le possibili cautele filologiche, ma fino in fondo e con decisione. Senza di questo, le mie incursioni nella teologia, nel diritto, nella politica, nella letteratura non sarebbero state possibili. In questo senso, Benjamin è il solo autore la cui opera ho voluto, nella misura delle mie forze ma senza riserve, continuare".
} 
em alemão"11 (AGAMBEN, 2017a, p. 101). Em seguida, uma das últimas e mais relevantes (para meus propósitos aqui) duplas formadas por Agamben em seu livro é a aproximação entre Benjamin e Giorgio Pasquali, filólogo italiano autor do clássico Storia della tradizione e critica del testo, de 1934. A junção de Pasquali e Benjamin se dá no próprio trabalho de Agamben a partir daqueles elementos salientados acima: restituir vida ao elemento extraído do contexto histórico a partir de um reposicionamento no presente, sempre com cautela filológica. A cautela filológica é uma espécie de "consciência crítica da tradição", acrescida, por sua vez, da percepção que o objetivo dessa leitura filológica específica não é o original, mas o processo de "escovar a contrapelo" a "viva história da tradição" de um texto. "O original em sua verdade", escreve Agamben, "não se situa no passado, mas tem seu lugar no presente, no instante no qual o filólogo - ou o filólogo que está em todo leitor politicamente consciente - se choca corpo a corpo com a tradição, naquilo que Heidegger definia como uma 'destruição' inexorável e sem reservas”'12 (AGAMBEN, 2017a, p. 114-115).

$\mathrm{O}$ estilo tardio se relaciona com a rememoração de Agamben em Autoritratto nello studio em um primeiro modo mais facilmente reconhecível: trata-se de uma reorganização retrospectiva do próprio trabalho, assinalando, por um lado, os eixos mais importantes e com maior potencial de canonicidade e, por outro lado, corrigindo eventuais desvios de recepção da parte dos críticos de sua obra ${ }^{13}$. Gostaria de salientar um segundo modo, mais sutil, pelo qual o estilo tardio é reconhecível na escrita de Agamben em Autoritratto nello studio: não se trata de constatar ou não o uso da expressão "estilo tardio" em Agamben, mas de observar que é precisamente no exercício do estilo tardio que a tensão entre tradição acumulada e leitura situada no presente fica mais evidente. $\mathrm{Na}$ medida em que se posiciona no final de uma dada tradição heterogênea e composta de estratos diversos, Agamben acessa, indiretamente,

${ }^{11}$ Tradução minha. No original: "chiara e leggibile quando scriveva in francese, ma ardua da decifrare se scriveva in tedesco".

${ }^{12}$ Tradução minha. No original: "L'originale nella sua verità non si situa nel passato, ma ha il suo luogo nel presente, nell' istante in cui il filologo - o il filologo che è necessariamente in ogni lettore politicamente cosciente - si scontra corpo a corpo con la tradizione, in quella che Heidegger definiva a ragione una 'distruzione' inesorabile e senza riserve”.

${ }^{13}$ Em artigo recente, intitulado "Dieci brevi note su Giorgio Agamben, l'Università, e la trilogia non dichiarata" ("Dez notas breves sobre Giorgio Agamben, a Universidade e a trilogia não declarada”), Leonardo Caffo argumenta que a obra tardia de Agamben enfatiza a necessidade de afastar o pensamento da burocratização, especialmente no que diz respeito à atuação da filosofia como disciplina no âmbito universitário. $\mathrm{O}$ ensaio de Caffo mostra a produtividade do recorte que leva em consideração o estilo tardio: seu recorte é diverso do meu, pois aproxima Autoritratto nello studio de outros dois livros de Agamben que não utilizo (Pulcinella ovvero Divertimento per li regazzi, de 2015, e Che cos'è reale? La scomparsa di Majorana, de 2016), mas o campo argumentativo é compartilhado. Escreve Caffo: "No momento em que escrevo Agamben tem cerca de oitenta anos e a vontade de transformar sua filosofia em um balanço é evidente a quem segue suas pesquisas com atenção; o ensaio sobre Pulcinella (2015), aquele sobre Majorana (2017), e a autobiografa (2017), são a prova de uma trilogia construída sobre questionamentos à realidade (Majorana), à máscara (Pulcinella) e à vida (autobiografa)"; "Agamben está minando o edifício da filosofia de hoje pela base, recuperando, pela via do paradoxo, suas mais antigas origens ocidentais: os passeios de Sócrates com os alunos, a micro-comunidade como alternativa, a paixão pelo ócio" (CAFFO, 2017, p. 11 e 16). 
a dimensão própria ao estilo tardio ao condensar em um mesmo gesto crítico a reflexão sobre a peculiaridade de um percurso (seu autorretrato, sua elaboração crítica da própria obra) e a inserção desse percurso em um regime discursivo mais amplo (visível em Autoritratto nello studio a partir do contraste diante das figuras apresentadas em duplas).

4.

Por fim, gostaria de comentar o último livro lançado por Agamben até o momento, Studiolo, lançado em novembro de 2019. Trata-se de uma espécie de continuação de Autoritratto nello studio, na medida em que é também uma espécie de compilação de imagens favoritas: cada breve capítulo é construído como um comentário a uma coleção de imagens, "imagens amadas de modo especial" escreve o autor na "advertência" que abre o livro. "Studiolo", ensina Agamben na mesma advertência, é o termo utilizado para denominar - no Renascimento - o cômodo da casa para o qual se dirige o príncipe para ler e meditar, tendo à sua volta os quadros prediletos. O estilo tardio opera em Studiolo em um duplo registro: em primeiro lugar, no esforço de Agamben em apresentar um inventário crítico de suas imagens preferidas, uma sorte de testamento no qual recupera e organiza uma das vias de convivência do crítico com a arte; em segundo lugar, em certa recorrência sutil do comentário em torno a obras concebidas no final da vida, com destaque para três pintores: Giovanni Bellini, Hans Holbein e Diego Velázquez ${ }^{14}$. Se em seu "autorretrato" Agamben buscava apresentar imagens privadas (especialmente fotografias que, ao longo dos anos, fazia questão de manter próximas de si em seu local de trabalho), em Studiolo estamos diante de imagens públicas, reproduçôes de quadros amplamente difundidos e conhecidos. O gesto de base, contudo, é o mesmo: propor uma redescrição da tradição a partir de um ponto de vista particular, contingente - nas palavras de Edward Said, uma

\footnotetext{
${ }^{14}$ Em livro recente, também de 2019, outro pensador italiano retorna ao tema do estilo tardio. Trata-se de Roberto Calasso e seu alentado estudo sobre a Bíblia, Il libro di tutti i libri (O livro de todos os livros), editado pela Adelphi. No início do oitavo capítulo, Calasso inicia um comentário sobre o Moisés de Freud, uma obra carregada de "temores, hesitações, interrupçôes, justificativas", afirmando que aí se encontra com maior força seu "estilo tardio", de alguém que "nada ou pouco tem a perder" e que, por isso, arrisca criativamente em suas interpretaçôes (CALASSO, 2019, p. 299). Além disso, Calasso cita uma carta de Walter Benjamin a Gretel Adorno, datada de 9 de outubro de 1935 (quatro anos antes da publicação do Moisés de Freud, portanto), na qual Benjamin enfatiza a relação entre o estilo tardio de Freud e a intensidade lacunar de suas ideias (CALASSO, 2019, p. 516). É possível consultar também o comentário de Ilse Grubrich-Simitis ao estilo tardio de Freud em Moisés e o monoteísmo, no qual enfatiza a peculiar montagem histórica empreendida pelo autor - a articulação tensa entre o arcaico (Moisés no deserto) e a ordem do dia (a perseguição nazista e a fuga para a Inglaterra) (GRUBRICH-SIMITIS, 1997, p. 73-74). É preciso ainda salientar que o estilo tardio em Freud está diretamente ligado à sua entrada em um novo terreno de escrita, por ele denominada "romance histórico" (CALASSO, 2019, p. 307), elemento extensamente comentado por, entre muitos outros, Yosef Hayim Yerushalmi em seu O Moisés de Freud (1992, p. 42).
} 
reconfiguração das referências do passado que tanto está no presente quanto se coloca "à parte" do presente (SAID, 2009, p. 44).

Agamben não apenas exercita o estilo tardio em Studiolo como busca em certos pintores a repercussão estética do estilo tardio. É o caso de sua leitura da pintura de Bellini que ilustra a capa do livro: Noé, velho e bêbado, sendo coberto por seus filhos. Agamben comenta que Bellini não havia, até esse momento, pintado qualquer cena do Antigo Testamento - seu interesse, portanto, não seria teológico, mas técnico; seu objetivo é dar conta da nudez do corpo envelhecido. "O tema do quadro", escreve Agamben, "não é a nudez, mas uma nudez que deve ser coberta. [...] A nudez que mostra Bellini é a sua, a de um velho que se pôs a nu em sua obra e que agora quer apenas ser coberto [...] Ao mestre importa apenas o jogo das seis mãos ao redor do corpo branco, luminoso"15 (AGAMBEN, 2019, p. 5). Agamben ainda destaca que a peculiar representação da cena proposta por Bellini é composta por quatro camadas referenciais heterogêneas e sobrepostas: em primeiro lugar, o resgate da história bíblica, em Gênesis 9, 20-27; em segundo lugar, o corpo de Noé em primeiro plano está em uma posiçáo muito semelhante à Vênus pintada por Giorgione pouco tempo antes; em terceiro lugar, um relevo no Palazzo Ducale de Veneza, frequentemente observado por Bellini e que mostra um dos filhos de Noé cobrindo seu corpo com um manto; em quarto lugar, Agamben aponta que a pintura de Bellini também evoca o gênero da Pietà, evocando, simultaneamente, uma deposição no sepulcro.

No quadro de Bellini, portanto, feito um ano antes de sua morte, Agamben destaca aqueles que são os elementos decisivos para o estilo tardio: reconfiguração da tradição, convivência tensa de temporalidades e ênfase no tema da morte. Todos esses elementos retornam, algumas páginas adiante, no capítulo de Studiolo dedicado ao comentário de uma tela de Ticiano, $O$ esfolamento de Mársias. Agamben escreve que se trata de uma das últimas telas pintadas por Ticiano, feita em paralelo com sua Pietà (que permaneceu incompleta). Em primeiro plano, pendurado de cabeça para baixo, está mais uma vez o corpo morto - desta vez de Mársias, o sátiro que desafiou Apolo para um duelo musical. Ticiano, "através de uma série de detalhes significativos", escreve Agamben, não quis representar "somente um episódio da mitologia grega, mas algo que diz respeito a ele em primeira pessoa, de modo tão íntimo que o espectador se sente interpelado à meditação como se estivesse diante de uma imagem sacra"16 (AGAMBEN, 2019, p. 25). Assim como em Bellini, o estilo tardio

\footnotetext{
${ }^{15}$ Tradução minha. No original: "Il tema del quadro non è, allora, la nudità, ma una nudità che deve essere coperta. [...] La nudità che egli mostra è la sua, quella di un vecchio che si è denudato nella sua opera e ora vuole soltanto essere coperto [...]. Al vecchio maestro importano soltanto il gioco delle sei mani che sembrano rincorrersi e chiamarsi, le linee orizzontali dei ginocchi e dei gomiti - e poi ancora quel rosso, che si vena d'oro a contatto del corpo cosí bianco, cosí luminoso".

${ }^{16}$ Tradução minha. No original: "attraverso una serie di particolari significativi, non ha voluto rappresentare, come aveva fatto altre volte, soltanto un episodio della mitologia greca, ma qualcosa che lo riguarda in prima persona e cosí intimamente, che lo spettatore si sente interpellato alla meditazione come se si trovasse davanti a una immagine sacra".
} 
em Ticiano se manifesta com a presença da morte (Noé e Mársias) e com o resgate de uma tradição arcaica (a bíblica em Bellini, a mitologia grega em Ticiano). Ticiano, contudo, complexifica a questão ao se colocar diretamente no quadro: o pintor reconfigura a tradição, acrescentando um autorretrato seu como rei Midas (que olha diretamente para o corpo de Mársias, ao contrário do desenho de Giulio Romano, base para o quadro de Ticiano, no qual Midas cobre os olhos).

Agamben argumenta que Ticiano busca escapar da explicação canônica da cena do esfolamento de Mársias, ou seja, a versão (que se encontra na Biblioteca de Apolodoro, nas Fábulas de Higino e na Biblioteca histórica de Diodoro Sículo) de que se trata de uma punição. Além de se colocar como participante e testemunha, Ticiano propóe o esfolamento como uma metáfora da inspiraçáo, baseado no aparecimento de Mársias no primeiro canto do Paraíso de Dante. Aqui vale a pena citar de forma mais extensa a argumentação de Agamben (o parágrafo de encerramento do capítulo), aproveitando a recente tradução de Vinícius Nicastro Honesko:

Ainda que os estudiosos de iconologia com frequência indaguem, para suas interpretaçóes dos quadros, textos insólitos e raros, podemos aqui presumir, com razoável verossimilhança, que Ticiano, em suas inegáveis leituras da Comédia, tenha sido tocado por essa passagem e dela tenha retirado a ideia de fazer do esfolamento do sátiro a alegoria da abissal dificuldade da inspiração do pintor. Assim como Dante havia transferido o significado do episódio da música à poesia, também Ticiano a desloca da poesia para a pintura. A inspiração que ele persegue para sua última investida situa-se em uma zona obscura e dolorosa entre o inumano e o humano e entre o animal e o divino. O corpo que ele, já velho, contempla enquanto bem ou mal é esfolado vivo é, de algum modo, o seu, mesmo se mais jovem e próximo da natureza perdida. Em todo caso, contra Apolo e de maneira diversa que em Dante, o que aqui acontece não pode ser expresso em palavras. Ovídio, em sua descrição do suplício de Marsias, havia colocado em evidência o lamento: "Por que me esfola? - pergunta - Ai! Lamento - gritava -, a flauta não vale tanto!" e, "não obstante seus lamentos, a pele era-lhe arrancada pelos artífices e não era nada mais que uma única laceração" (Met. VI, 382-400). É a tal lamento - não à música divina, não à palavra humana - que Midas dá ouvidos com suas orelhas de burro; é esse débil, incessante e ilegível lamento que está em questão na última pintura de Ticiano (HONESKO, 2018, p. 15).

Além de frisar a inserção de um autorretrato de Ticiano no esfolamento de Mársias, Agamben chama a atenção para a possibilidade do corpo morto ser aquele do próprio pintor, envolvido na "abissal dificuldade da inspiraçáa". A fonte escrita imediata de Ticiano seria a Comédia de Dante (sete ediçóes do poema foram impressas em Veneza durante a vida do pintor, informa Agamben), e não os textos mais antigos e esperados pela iconolo- 
gia tradicional e pela recepção imediata no contexto histórico imediato de Ticiano. Nesse sentido, o pintor atuava "contra a corrente de seu tempo", para usar a expressão de Edward Said apresentada no início deste artigo (SAID, 2009, p. 42). Ademais, o uso que Bellini faz do corpo de Noé (também uma espécie de autorretrato com uma figura ambivalente, tanto viva quanto morta) e que Ticiano faz do corpo de Mársias (metáfora da inspiração que é observada, no interior do quadro, pelo próprio artista) se alinha diretamente com aquilo que escreve Said: "o estilo tardio não admite as cadências definitivas da morte; nele, ao contrário, a morte aparece como refração, como ironia” (SAID, 2009, p. 44).

Em Studiolo, o estilo tardio de Agamben realiza uma torção sobre si próprio ao refletir sobre o estilo tardio de artistas como Bellini e Ticiano, rastreando em suas obras finais os elementos de redescrição que venho apontando. Como escreve o próprio autor, "a aposta sobre a qual se funda todo comentário filosófico é que o momento no qual a obra é produzida não coincide necessariamente com aquele de sua legibilidade"17, ou seja, não se trata de restringir a validade de um comentário a um contexto histórico específico, e sim postular a multiplicidade de comentários válidos diante da variaçáo dos contextos disponíveis (AGAMBEN, 2019, p. ix-x) ${ }^{18}$. O estilo tardio surge, portanto, como uma ferramenta de atuação sobre os múltiplos estratos históricos dos textos, salientando - através de sua típica intensidade na correlaçáo de dados e detalhes - o caráter contingente e provisório de toda interpretação.

\footnotetext{
${ }^{17}$ Tradução minha. No original: "La scommessa su cui ogni commentario filosofico si fonda è, infatti, che il momento in cui l'opera è stata prodotta non coincide necessariamente con quello della sua leggibilità".

${ }^{18}$ É em torno desse problema bastante amplo que Hans Ulrich Gumbrecht organiza "Cascatas de modernidade", o texto de abertura de sua coletânea Modernização dos sentidos, especialmente quando declara que, no que diz respeito ao período entre 1780-1830, segue "a tese de Reinhart Koselleck sobre o assim chamado Sattelzeit ('período da sela') entre 1780-1830. Ela implica que, de um ponto de vista hermenêutico, a outridade dos textos anteriores a 1780 sempre ameaça exceder as possibilidades da nossa compreensão, ao passo que estamos constantemente correndo o risco de nos sentirmos excessivamente familiares com textos posteriores a 1830. [...] A descrição de Michel Foucault de um 'corte' epistemológico por volta de 1800 pode ser lida como uma versão mais dramática da mesma observação. [...] Embora a auto-referência 'oficial' de Desconstrução exclua tal perspectiva, Jacques Derrida tentou repetidamente fundamentar sua própria posição filosófica nas mesmas complexificaçôes epistemológicas com as quais operam Koselleck e Foucault" (GUMBRECHT, 1998 , p. 28). Meu objetivo aqui foi o de mostrar que a discussão em torno ao estilo tardio tangencia esse contexto mais amplo, na medida em que propóe sempre uma peculiar junçáo da experiência privada (o autorretrato, a evocaçáo, a reminiscência) com a tradição compartilhada (todo o oposto das tentativas de periodização em bloco de Koselleck, Foucault e Gumbrecht). Para uma discussão do Sattelzeit de Koselleck, consultar o artigo de Marcelo de Mello Rangel, "Romantismo, Sattelzeit, melancolia e 'clima histórico' (Stimmung)" (RANGEL, 2014, p. 53-62).
} 


\section{Referências}

AGAMBEN, Giorgio. Studiolo. Turim: Einaudi, 2019.

AGAMBEN, Giorgio. Signatura rerum: sobre o método. Trad. Andrea Santurbano, Patricia Peterle. São Paulo: Boitempo, 2019a.

AGAMBEN, Giorgio. Autoritratto nello studio. Milão: Nottetempo, 2017a.

AGAMBEN, Giorgio. Principia Hermeneutica. Trad. do italiano para o francês Joël Gayraud. Revue Critique, n. 836-837, p. 5-13, 2017 b.

AGAMBEN, Giorgio. Il fuoco e il racconto. Roma: Nottetempo, 2014.

AGAMBEN, Giorgio. Opus Dei: arqueologia do ofício: Homo Sacer, II, 5. Trad. Daniel Arruda Nascimento. São Paulo: Boitempo, 2013.

AGAMBEN, Giorgio. Nudità. 3 ed. Roma: Nottetempo, 2010.

AGAMBEN, Giorgio. O que é o contemporâneo? e outros ensaios. Trad. Vinícius Nicastro Honesko. Chapecó: Argos, 2009.

AGAMBEN, Giorgio. O que é um dispositivo?. Revista Outra Travessia, n. 5, p. 9-16, 2005.

BROWN, Norman O. Apocalypse and/or Metamorphosis. Berkeley: University of California Press, 1991.

BROWN, Norman O. Closing Time. Nova York: Random House, 1973.

BROWN, Norman O. Vida contra morte: o sentido psicanalítico da história. Trad. Nathanael Caixeiro. Petrópolis: Vozes, 1972.

CAFFO, Leonardo. Dieci brevi note su Giorgio Agamben, l'Università, e la trilogia non dichiarata. Rivista Animot. L'altra filosofia, Turim, v. IV, n. 7, p. 10-19, jul./dez. 2017.

CALASSO, Roberto. Il libro di tutti i libri. Milão: Adelphi, 2019.

CLEMENTE, Pietro. Per Giorgio Baratta. Prove d'orchestra. Lares, Rivista quadrimestrale di studi demoetnoantropologici, Florença, v. 77.3, p. 445-458, set./dez. 2011.

GRUBRICH-SIMITIS, Ilse. Early Freud and Late Freud: Reading Anew Studies on Hysteria and Moses and Monotheism. Trad. Philip Slotken. Londres: Routledge, 1997.

GUMBRECHT, Hans Ulrich. Modernização dos sentidos. Trad. Lawrence Flores Pereira. São Paulo: Editora 34, 1998.

HONESKO, Vinícius Nicastro. Tradução: “O esfolamento de Marsias”, de Giorgio Agamben. Revista Diálogos Mediterrânicos, n. 14, p. 12-15, 2018.

KERMODE, Frank. A sensibilidade apocaliptica. Trad. Melo Furtado. Lisboa: Ediçóes Século XXI, 1997.

KOSELLECK, Reinhart. Estratos do tempo: estudos sobre história. Trad. Markus Hediger. Rio de Janeiro: Contraponto, PUC-Rio, 2014. 
KOSELLECK, Reinhart; MEIER, Christian; GÜNTHER, Horst; ENGELS, Odilo. $O$ conceito de História. Trad. René E. Gertz. Belo Horizonte: Autêntica, 2013.

RANGEL, Marcelo de Mello. Romantismo, Sattelzeit, melancolia e "clima histórico" (Stimmung). Revista Expediçôes: Teoria da História \& Historiografia, v. 5, n. 2, jul.-dez. 2014, p. 53-62.

SAID, Edward W. Estilo tardio. Trad. Samuel Titan Jr. São Paulo: Companhia das Letras, 2009.

SAID, Edward W. Closing Time, by Norman O. Brown. The New York Times Book Review, 9 set. 1973 , p. 417.

VILLAÇA, Alcides. Edward Said e o "estilo tardio". Revista Estudos Avançados, v. 24, n. 68, p. 375-380, 2010.

WHITE, Hayden. Trópicos do discurso: ensaios sobre a crítica da cultura. Trad. Alípio Correia de Franca Neto. São Paulo: Edusp, 2014.

YERUSHALMI, Yosef Hayim. O Moisés de Freud: judaísmo terminável e interminável. Trad. Júlio Castañon Guimaráes. Rio de Janeiro: Imago, 1992. 